\title{
에코세대의 부의 세대간 이전과 부동산투자 결정요인 연구
}

\author{
정원일* 김호정**
}

본 연구는 에코세대를 대상으로 하여, 주택매입과 부동산투자에 대한 결정요인을 분 석하였다. 이를 위해 우선, 에코세대의 주택구입 결정요인 특징을 로짓모형을 통해 살 펴보았다. 실증분석결과 에코세대가 그 이외 세대보다 부모지원이 내집마련 결정에 영향을 미치는 계수값이 크게 추정되었다. 이는 에코세대에서의 부모지원이 다른 세 대보다 내집마련 결정에 더 중요한 요소인 것으로 해석할 수 있다.

통념적으로 에코세대의 소득수준은 다른 세대에 비하여 낮기 때문에 투자에 있어 소 극적이라 생각되지만, 소득은 내집마련 결정에 상대적으로 영향력이 낮게 추정되었고 결국 부모의 지원이 다른 변수보다 중요한 결정요인으로 작용하고 있다. 즉, 에코세대 는 기존 통념과 달리 부의 세대간 이전을 활용하여 부동산투자를 하고 있으며, 이는 향후에도 주택시장은 에코세대가 중요한 실수요자로서 그 역할을 할 것으로 기대할 수 있다.

따라서 주택수요 및 주거형태에 대한 분석을 진행함에 있어서 세대별로 다른 패턴이 발생하는 동시에 새로운 요소인 부의 세대간 이전이라는 항목이 추가로 고려되어야 할 것이다. 급격히 변해가는 인구구조와 특징변화에 맞춰 세대를 구분하여 주택의 실 거주 및 자산으로써의 수요를 파악하는 것이 향후 정책적 선택에 있어 중요할 것으로 강조된다.

* 유안타증권 리서치센터 이코노미스트, 경제학 박사, wonil.jeong@yuantakorea.com, 제1저자, 교신저자

** 유안타증권 리서치센터 연구원, 경제학 석사, hojung.kim@yuantakorea.com, 공동저자

※ 본고의 내용은 필자의 개인 의견으로 한국주택금융공사의 공식적인 견해와 다를 수 있습니다. 


\section{I . 서론}

주택 관련 뉴스는 주요한 사항으로 언론을 통해 매일 접하게 된다. 주택이 우리 삶에 있어서 중요한 이유는 무엇일까? 주택이란 것은 단순 거주의 의미뿐만 아니라 자산효과를 나타낼 수 있고, 이를 통한 가계의 소비성향에도 주요하게 작용한다. 본 연구는 에코세대를 대상으로 주택 시장에서의 주택 매입 및 투자를 결정하는 요인에 대해 분석하고 이에 대한 시사점에 대해 논하 고자 한다.

우리나라 주택시장의 흐름을 점검해보면, 아파트 매매가격과 전세가격의 추이가 그 변화의 폭은 차이가 있지만 유사한 추세를 보이는 것이 특징이다. 특히 금융위기 이후의 전세가격 변화 율이 매매가격 변화율보다 지속적으로 높은 모습을 보이고 있음을 알 수 있다. 또한 정부의 대 책도 과거는 부동산정책이 투기대책이나 가격급등에 따른 시장안정대책이었던 것과는 달리 거 래 활성화 및 전월세안정과 주거안정화대책에 집중되고 있는 것으로 나타난다.

금융위기 이후 국내주택시장은 인구고령화와 베이비부머세대의 은퇴까지 맞물려 주택시장구 매심리가 하락하고 주택신규구매계층의 주택구매에 필요한 소득여력까지 하락하면서 소유보다 는 임차수요가 증가하였다. 금융위기 이후 시기 특징으로 주택수요계층이 주택가격하락을 예상 함에 따라 주택을 소비해야 함에도 불구하고 소유보다는 임차의 형태로 소비시장에만 머물며 관망하는 자세가 특징으로 나타났다. 이러한 모습은 주로 에코세대에 해당한다.

베이비부머 세대는 주로 근로소득과 저축을 통해 주택을 마련하였다. 이후 꾸준한 주택가격 상승을 경험한 베이비부머와 그 이전 세대들에게는 현재의 주택가격 형성에 익숙하지만, 경제 위기를 경험하고, 이러한 경험이 없는 에코세대에게 주거마련은 다른 형태로 다가온다고 설명 하였다. 결국 오늘날과 같은 주택가격구조는 결과적으로 에코세대의 자가 마련과 주택시장 진 입을 쉽지 않게 만들었다. 즉, 정부의 주거안정화대책은 모든 세대에 영향을 받지만 주거를 마 련해야하는 에코세대에 있어 상대적으로 더욱 민감할 수 있다.

에코세대는 베이비부머 세대의 자녀세대로 2019년 기준 30대 후반 40대 초반 세대에 해당 한다. 다른 세대보다 상대적 풍요로운 성장과정을 거쳤고, 높은 교육열과 문화적인 혜택을 받으 며 자란 특성을 지녔다. 다만 에코세대의 실업, 부채, 낮은 저축수준과 높은 주거비는 주택구매 의욕 상실 현상을 가져왔고, 에코세대는 부모의 도움이 없이는 주택을 구매하기는 현실적으로 쉽지 않은 상황이다.

에코세대가 신혼주택을 마련하는데 스스로의 여력은 부족하여 부모 또는 금융기관에서 도움 
을 받고 있지만 실질적인 수요자는 에코세대이다. 이는 주택시장에서 에코세대들이 선호하는 중소형 규모를 중심으로 주택시장 변화가 나타나고 있는 것에서도 확인할 수 있으며, 향후에도 주택시장은 에코세대가 중요한 실수요로서 그 역할을 할 것으로 전망하고 있다.

따라서 본고의 구성은 다음과 같다. 제2장에서는 선행연구로 주택 선택요인을 자산적 측면, 가격의 측면 등 경제적 관점에 대해 살펴보고, 현상적인 측면에서 주택 소유와 거주 간 불일치, 기타 결정요인 등을 고찰해본다. 제3장에서는 분석자료 및 기초통계분석으로 에코세대 주거형 태의 특성 및 주택수요에 대하여 분석하였다. 제4장에서는 실증분석 결과로, 주거실태조사를 활용한 내집마련 결정요인과 가계금융복지조사를 활용한 부동산투자 결정요인에 대해 실증분 석하였다. 마지막으로 제5장에서 결론 및 정책적 시사점을 정리한다.

\section{II. 선행연구 검토}

주택을 소유한다는 것은 경제적인 요인뿐만 아니라 다양한 요인에 영향을 받는다. 주택소유 에 대한 연구는 경제적 측면에서 주로 검토가 되었다. 또한 많은 연구들이 고령자 또는 기성세 대를 중심으로 주거안정성, 자산특성, 부동산 자산구조에 대한 연구는 많으나 주택시장에서 새 롭게 부상하고 있는 에코세대에 관한 연구는 부족한 실정이다.

주택소유의 경제학적 메커니즘을 살펴보면 그 출발점은 자산이다. Artle and Varaiya(1978) 에서는 주택구입자금이 가계의 유동성 제약으로 작용함을 보였으며, 주택을 소유하기를 원함에 따라 가구의 소비를 줄여 자산을 축적하고, 주택소유 후에 소비를 정상화시키는 과정을 증명하 였다.

Brueckner(1986)는 2기간 효용극대화 모형을 이용하여 점유형태 변화과정에서 주택구입자 금제약이 가구소비와 주택소유에 영향을 미친다는 것을 이론적으로 분석하였으며, Plaut(1987) 에서는 위험회피 성향의 가구는 주택가격변동의 불확실성하에서, 주택가격상승으로 구매에 대 한 위험을 상쇄하기 위해서 원래 필요량보다 더 많은 자본을 축적하여 대처할 수 있음을 실증분 석을 통해 확인하였다.

Jones(1990)는 주택점유형태 선택에 있어, 자산의 잠재적 중요성에 집중하였다. 해당연구에 서는 젊은 에코세대라고 할 수 있는 생애 최초 주택구입가구인 18 세에서 34 세의 결혼가구를 대상으로, 현 주택수요를 추정하였다. 그 결과 임시소득도 항상소득과 함께 주택수요에 중요한 
영향을 미치는 요인으로, 현재자산의 주택수요에 대한 탄력성이 소득탄력성보다 더 크다고 분 석하였다.

Hendershott and Wachter(1997)에서는 에코세대라 할 수 있는 젊은 임차가구에 대한 실 증분석을 통해 소득과 자산에 대한 대출제약조건을 최소화할 수 있는 LTV를 선택해도, 대출제 약조건에 직면하게 되며 이러한 제약조건은 주택소유 확률을 감소시켜, 결국 주택을 소유하기 위해서는 충분한 자산축적이 이루어져야 함을 밝히고 있다.

한편, 주택결정에 있어 자산과 관련한 요인에 관한 국내연구로 여윤경(2005)은 가계 순자산 규모의 결정요인과 관련하여 연령에 따른 유의한 차이가 없음을 확인했다. 가계 재무구조를 자 산과 부채로 구분하여 생애주기별로 분석하였다. 총자산과 순자산 모두 가구주 연령이 50대에 가장 높은 수준이며, 주택자산 비중은 연령에 따라 크게 변화하지 않았고, 연령효과도 가구주 특성이나 기타 경제변수를 고려한 경우에는 통계적으로 유의하지 않은 것으로 나타났다.

여윤경, 주소현(2009)은 가계의 순자산과 자산배분과의 관계를 밝혔는데, 우리나라 가계는 가구주 연령, 교육수준 등의 주요변수들을 통제한 상태에서도 위험자산과 투자부동산의 비중이 크고, 부채의 비중이 작을수록 순자산이 많은 것으로 나타났다. 또한 순자산 수준은 실물자산, 위험자산, 부채비중에 모두 유의한 영향력을 미쳤으며, 자산배분결정과 가계의 순자산이 상호 영향을 미치고 있음을 밝혀냈다.

주택결정의 또 다른 요인은 바로 가격이다. 주택가격은 한경제의 상황과 기대를 담고 있다. 예를 들어 차입자의 입장에서는 금리와 같은 실물경제의 흐름만 반영하는 것뿐만 아니라 소득 과 주택시장 참여자들이 기대하는 합리성도 반영하고 있다.

주택가격이 상승할 때 향후 더 오를 것이라는 기대가 반영될 경우 실물경제는 기대 수준만큼 상승할 수도 있고 그 이상도 가능하다. 반대로 주택가격이 떨어질 것이라는 기대가 작용하고 심 리가 위축될 경우 더 큰 폭으로 하락할 수 있는 것이 주택가격이다. 행동경제학의 입장에서, Kahneman and Tversky(1991)에서는 손실회피성향이 주택시장에도 적용된다고 볼 수 있다 고 보았으며, 위와 같은 맥락이다.

주택의 수요량과 주택공급간 불균형이 발생하면 균형 수준을 조정하기 위해 공급조절을 통한 수량조절이 필요하고, 가격조정을 통한 조정이 이루어지게 되는데, 이 과정에서 가격은 변화하 게 된다. 이때 시장가격 상승 탄력이 높을수록 가격에 상승 폭에 대한 기대심리가 나타나게 되 고 수요를 증가시킬 유인이 발생하게 된다. 즉, 가격상승에 대한 기대수요가 반영되며 가격이 상승하게 되는 것이다.

최막중, 고진수(2006)는 유동성에 초점을 두었다. 아파트와 단독주택의 유동성 차이가 존재 
한다는 가설에서 출발하여, 아파트가 단독주택에 비해 유동성이 높다는 것을 실증분석을 통해 확인했다. 가계의 유동성이 낮을 경우, 거래가격이 낮게 결정되는 가격할인효과가 나타나는 것 을 확인했으며, 아파트에 대한 선호는 일반적으로 주택이 지니는 내구재로서의 특성뿐만 아니 라 투자재로서의 특성에도 기인함을 설명하였다.

김태경(2009)은 거주와 소유가 동일한 가계와 거주와 소유가 분리된 가계의 소유회전율 차 이를 분석하였다. 거주와 소유가 동일한 가계는, 주거환경, 안정성에 방점을 두고 주택의 건축 연한, 가계의 라이프 서클 등이 소유회전율에 유의미한 영향을 미치는 반면, 거주와 소유가 분 리된 가계는 면적, 주택가격, 구성원의 성별 등 복합적인 측면이 보다 유의미한 영향을 미치는 것으로 나타났다. 김재현(2013)에서는 에코세대는 주거안정을 위한 자가 마련을 희망하지만 경제력이 부족하고 금융대출에는 소극적인 것으로 나타났다. 이에 생애주기를 고려한 주거이동 및 다양성을 반영하고 세대간 자산이동을 원활하게 할 필요성을 제시하였다.

이현정(2013)에서는 에코세대의 자가 마련에 미치는 영향요인으로, 실물자산이 많은 에코세 대의 여성일수록 자가 마련을 위한 부동산 투자목적 가능성이 높아다는 것을 분석했다. 반면 교 육수준, 주택의 점유형태, 금융자산, 부채액이 클수록 자가 마련의 가능성을 낮추는 것으로 분 석하였다. 또한, 에코세대는 실질적인 거주를 위해 아파트 장만에 역점을 두고, 상대적으로 풍 요로운 환경에서 성장한 에코세대는 라이프스타일을 중시하는 성향이 강하며, 경제위기로 자산 가치의 급락을 목격하고 다양한 금융상품의 등장과 선택을 접하면서 부모세대와 다른 자산 투 자 가치관을 형성하게 되었다. 이러한 세대간 투자관의 차이에도 불구하고 거주할 주택을 장만 해야 한다는 기본적인 가치관이 공유되는 것은 기성세대의 관념이 이어지는 것으로 해석하였다.

Ioannides and Rosenthal(1994)에서는 주택을 소유하는데 있어 중요한 요소를 투자수요 와 소비수요로 보고 있다. 투자수요는 소비수요에 비해 자산과 소득에 민감하며, 반대로 소비수 요는 투자수요에 비해 연령, 교육, 가구원수, 도심 접근성 등에 민감하게 반응하는 것으로 나타 난다고 분석하였다. Guiso and Jappelli(2002)는 주택소유 여부가 안전자산 및 위험자산 소 유를 결정하는 데 중요한 요인이며, 가계의 유동성, 결혼, 자녀의 출생 및 양육 등에 의해 영향 을 받는다는 결과를 도출했다.

최막중, 강민욱(2012)은 주택보유자임에도 차가로 점유하는 가구가 주택시장에서 차지하는 비율이 생각보다 높다는 점에서 출발하여, 주택의 소유와 거주의 분리 현상이 나타나는 원인이 주택에 대한 소비수요와 투자수요가 공간적으로 분리되어 나타난 결과임을 실증분석을 통해 확 인했다. 특히, 우리나라에서 소유와 거주간 분리 현상이 나타나게 된 것은 가파른 경제 성장으로 인한 소득의 증가와 주택가격 상승으로 소득과 주택가격 모두 높은 수준으로 빠르게 증가했던 
주택금융연구 VOL 3

것에 기인하며, 여기에는 전세 제도가 이러한 것을 가능하게 하는 역할을 했던 것으로 설명했다.

한편, 주택소유에 대한 소비자의 효용측면에서의 연구로 Dietz and Haurin(2003)에서는 연구에 따르면, 자가 점유시 주택에 대한 유지 보수에 더욱 신경을 쓰며, 자가 비중이 높은 타운 은 그렇지 않은 곳보다 범죄율이 낮게 나타난다고 분석했다. 이러한 사회적 편익과 별개로 가구 의 관점에서 살펴보면, 자가 소유는 단순 자산 소유에 따른 만족뿐만 아니라, 안정적 주거생활 로 인해 가정생활과 사회생활에 대한 참여도가 높게 나타나고, 신체적, 정신적 건강도 임차 가 구보다 큰 것으로 나타났다. 이러한 개인의 효용은 정량적으로 계산된 가치보다도 더 큰 가치를 가지고 있다고 밝히고 있다.

\section{III. 분석자료 및 기초통계분석}

\section{1. 자료 및 분석대상}

본 연구에서는 가계금융복지조사를 활용하여 에코세대의 주택매입과 부동산투자 결정요인에 대하여 살펴보고자 한다. 가계금융복지조사는 2012년부터 연간 1회 진행되는 조사로서 가계생 활수준과 자산, 부채, 소득 등의 규모와 구성 및 분포를 조사하고 있으며, 특히 가계의 미시적 재무건전성을 파악하기 위한 추적조사의 특징을 가지고 있다. 통계청에서 생성하고 있으며, 조 사대상은 전국 1 인 이상 약 20,000 가구를 대상으로 하고 있다. 특히 금융부문 10,000 가구와 복지부문 10,000 가구에 대하여 조사하고 있다.

금융부문 조사에서는 가구특성과 더불어 자산관련(실물자산, 금융자산, 자산운용, 부동산운 용 등), 부채관련(금융부채, 부채상환능력 등), 소득수준, 지출패턴 등이 조사되어 있다. 복지부 문에서는 금융부문과 중복되는 부분이 상당히 존재하지만 노후생활 등에 대한 조사가 추가로 진행되어 있는 것으로 볼 수 있다. 본 연구에서의 주요 목적은 에코세대와 그 이상 세대의 주택 매입, 부동산투자와 관련된 결정요인을 도출하는 것이기 때문에 가계금융복지조사 내에서 금응 부문 자료를 활용하여 분석을 진행하도록 한다.

한편 주택소유에 대한 보다 정교한 분석을 진행하기 위하여 필요한 데이터베이스로써 주거실 태조사가 있다. 동 자료는 2006년부터 2016년까지 격년으로 조사되어 오다가, 최근 매년 조사 로 변경되어 자료가 수집되고 있다. 동 자료는 지역별, 계층별 주거실태에 대하여 파악하고, 주 
택소요량 및 선호도 파악을 통하여 공급계획을 지원하는 동시에 주거복지 소요 파악 및 정부정 책 수립에 필요한 기초자료를 제공하기 위하여 조사되고 있다. 국토교통부에서 조사하고 있으 며, 조사대상은 전국기준 60,000 가구에 더하여 서울 12,000 가구, 경기 8,000 가구, 세종 1,900 가구를 추가로 조사하고 있다.

동 조사의 주요 조사내용은 주택 및 주거환경, 이사계획 및 주거의식, 정책평가 및 정책수요, 가구특성변수 등이 조사되고 있다. 특수가구에 대한 조사도 격년으로 조사되는데, 신혼부부, 노 인가구 등에 대한 조사가 추가되고, 지자체 별로도 경기도 및 서울시에 대하여 항목이 추가되어 조사되고 있다.

앞서 언급하였듯이 에코세대의 주택매입과 부동산투자 결정요인을 분석함에 있어서 그들이 거주하고 있는 주거형태에 대한 판단이 선행되어야 세대별로 다른 특색과 배경이 존재하기 때 문에 발생하는 부동산투자 수요를 확인할 수 있을 것으로 생각된다. 따라서 본 연구에서는 에코 세대의 주거형태에 대한 고찰을 주거실태조사를 통하여 먼저 살펴본 이후, 이와 같은 환경적인 특성에 더하여 부동산투자에 대한 결정요인을 분석하는 과정을 통하여 현 시대를 살아가는 주 력 세대의 주거패턴과 함께 자산수요로써의 주택투자 패턴을 확인하도록 한다.

\section{2. 에코세대의 주거형태: 주거실태조사 분석}

주거에 대한 환경을 분석하기 위해서 시계열적으로 변화되는 양상을 확인하는 것도 중요하지 만, 에코세대가 가구주가 되기 시작하는 시점은 불과 몇 년 지나지 않은 것으로 볼 수 있다. 따 라서 2006년부터 주거실태조사가 시행되어 있지만 본 연구에서는 수집할 수 있는 최신 자료인 2017년 기준으로 분석을 진행하도록 한다.

먼저 세대별로 구분하여 현재 거주하고 있는 주택의 유형1)을 살펴보면 〈표 1〉과 같은 결과 를 얻을 수 있다. 본 연구에서 에코세대로 정의하는 39세 이하 세대의 주거형태는 일반단독주 택의 비율이 가장 낮은 $2.4 \%$ 수준인 것을 볼 수 있다. 연립다세대와 아파트 거주자의 비중은 각 각 33.3\%와 57.4\% 수준을 기록하고 있으므로 아파트에 거주하는 가구 비중이 가장 높은 것으 로 볼 수 있고, 오피스텔 등 기타 주거형태를 가진 가구의 비중도 $6.9 \%$ 수준을 기록하고 있다.

1) 주거실태조사에서는 총 11 가지의 주택유형으로 구분하여 조사가 진행되었다. 본 연구에서는 편의를 위하여 일 반단독주택, 연립/다가구/다세대, 아파트, 기타의 4가지의 유형으로 구분하도록 한다. 연립/다가구/다세대에 포 함되는 주거형태는 다가구단독주택, 영업겸용단독주택, 연립주택, 다세대주택이 있으며, 기타에 포함되는 형태 는 비거주용건물내 주택, 오피스텔, 고시원, 판잣집, 비닐하우스, 컨테이너, 기타 등이 있다. 
그런데 에코세대와 다른 세대와의 주거형태를 비교해보면 단독주택의 비중은 60 세 이상이 가 장 높고, 아파트의 비중은 40대에서 가장 높은 특징을 보이고 있다. 한편 기타 주거형태의 비율 은 30대 이하에서 가장 높은 비율을 보이고 있다.

이상에서의 결과를 토대로 에코세대를 위주로 한 우리나라의 세대별 주거형태의 특징을 해석 하자면 에코세대는 경제활동을 활발히 하고 있는 40 50대에 비하여 아파트 비중이 낮은 대신 연립/다세대/다가구 등의 비중이 높은 것이 확인되며, 특히 오피스텔 등 기타 주거형태도 상대 적으로 비중이 높은데, 주거에 대한 결정에서 가장 중요한 요소인 주택가격 혹은 임대료 측면에 서 아파트가 다른 주거형태에 비하여 가격이 높기 때문에 발생하는 현상인 것으로 해석할 수 있 다. 따라서 시간의 흐름에 따라 생애주기에 기초한 소득수준이 높아지는 과정에 진입하면서 점 차 주거형태가 아파트 등 고가주택으로 이동하는 모습을 볼 수 있을 것으로 생각된다.

한편 에코세대의 주거에 대한 점유유형2)을 살펴보면 다음과 같은 특징이 발견된다. 동 세대 의 자가에 대한 비중은 $33.5 \%$ 수준이며, 전세 $24.0 \%$, 월세/기타 $42.4 \%$ 정도로 구성되어 있다. 그런데 40 대 이상의 동 비율을 비교해보면 자가 비율이 빠르게 상승하는 것이 확인된다. 40 대 150 대/ 60 대 이상의 자가 비율은 각각 $56.4 \%, 63.4 \%, 74.1 \%$ 인 것을 감안한다면 에코세대는 상대적으로 목돈이 적은 이유 등으로 비용적인 측면에서 좀 더 낮은 임차 형태로 거주를 하는 것으로 볼 수 있다. 〈그림 1〉에서 확인되듯이 출생년도 별로 내집마련 성공 여부에 대한 분포를 살펴보면 동일한 맥락에서 비율을 확인할 수 있다. 아직 내집마련을 하지 못했다고 응답한 가구 의 연령분포가 가장 높은 연령이 39세로 확인되고 있고, 내집마련 성공자의 분포는 연령이 높 아짐에 따라 비중이 높아지는 특징을 보이고 있다.

<표 1> 2017년 기준 세대별 주거형태/점유유형 비교(단위: \%)

\begin{tabular}{|c|c|c|c|c|c|c|}
\hline & & 39세 이하 & 40 49세 & 50 59세 & 60세 이상 & 전체 \\
\hline \multirow{4}{*}{ 주거형태 } & 일반단독주택 & 2.4 & 5.9 & 12.6 & 34.1 & 20.6 \\
\hline & 연립/다가구/다세대 & 33.3 & 23.6 & 29.4 & 26.5 & 27.5 \\
\hline & 아파트 & 57.4 & 68.7 & 56.0 & 37.9 & 49.4 \\
\hline & 기타 & 6.9 & 1.9 & 1.9 & 1.5 & 2.4 \\
\hline \multirow{3}{*}{ 점유유형 } & 자가 & 33.5 & 56.4 & 63.4 & 74.1 & 63.3 \\
\hline & 전세 & 24.0 & 19.0 & 13.4 & 7.6 & 13.0 \\
\hline & 월세/기타 & 42.4 & 24.7 & 23.2 & 18.3 & 23.7 \\
\hline
\end{tabular}

2) 점유유형에 대한 구분은 주거실태조사에서 총 7 가지로 구분된다. 본 연구에서는 자가, 전세, 월세/기타로 구분하 도록 한다. 월세/기타에 포함되는 점유유형은 보증금있는 월세, 보증금없는 월세, 사글세 또는 연세, 일세, 무상 이 포함되어 있다. 


\section{<그림 1> 출생년도별 내집마련 여부 분포}

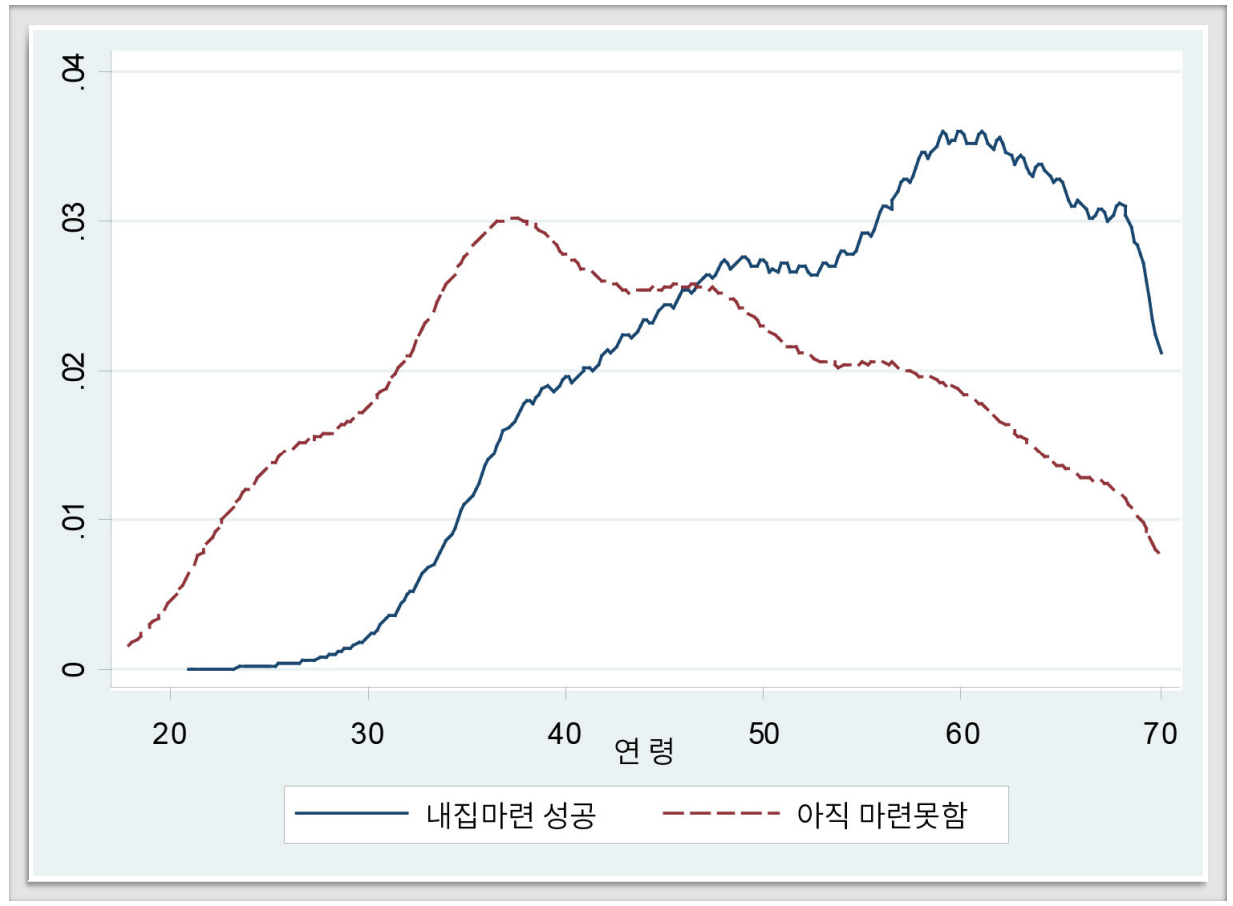

이상과 같은 주거형태와 점유유형으로 볼 때, 향후 주택매매시장에서의 가장 주된 집단으로 부상할 수 있는 세대가 바로 에코세대인 것으로 해석할 수 있다. 주거형태가 상대적으로 아파트 보다 선호도가 낮은 연립다세대 및 기타 형태의 비중이 높은 것과 더불어 자가의 비중이 낮다는 것으로 볼 때 향후 주택구매에 대한 잠재적 수요는 에코세대에 집중될 것으로 생각된다.

한편 세대별로 구분하여 주택마련을 위한 자금조달방법을 조사할 필요가 있다. 경제발전 단 계별로 상이한 자금조달방법이 연출될 것으로 예상되는데, 사실 부동산이라는 자산 역시 경제 규모가 적을수록 축적이 그리 크게 되어 있지 않을 것이나 지속적인 경제성장을 통하여 국가 전 체의 부가 증가할수록 축적되는 속도 역시 빠르게 될 것이라 판단된다. 중요한 점은 경제성장에 따라서 축적되어 있는 부의 세대간 이전이 발생할 가능성이다. 한국의 경제 특징은 일제강점기 후 전쟁을 거치면서 최빈국 수준의 경제규모에서 급속도로 발전된 경험이 있다. 따라서 세대별 로 구분해보면 현재의 베이비부머 세대는 그들의 부모 세대 역시 축적되어 있는 부가 크지 않았 기 때문에 부의 세대간 이전 역시 발생할 가능성이 낮은 것으로 생각할 수 있다. 그러나 경제성 장이 급속히 진행되면서 베이비부머 세대의 부가 증가한 상황, 그리고 이들이 본격적으로 은퇴 연령에 접하게 되면서 이들이 축적한 자산 역시 세대간 이전이 발생하기 시작한 국면으로 생각 
할 수 있다.

〈표 2〉에서는 세대별 주택자금 조달방법에 대한 기초통계를 산출한 결과이다. 1960년대생 의 경우에는 본인마련의 비중이 $80 \%$ 를 넘어서고 있는 모습이 확인되고, 금융기관대출을 통한 조달이 $18.4 \%$ 수준을 보이고 있다. 그런데 연령이 낮아질수록 본인마련 비중은 낮아지는 것을 볼 수 있다. 에코세대의 금융기관대출 비중을 보면 $22.7 \%$ 를 기록하는 등 금융시장의 발전에 따 라 조달방법이 조금씩 달라지는 것을 볼 수 있고, 특히 부모지원 항목의 비중이 크게 높아진 것 으로 볼 때 부의 세대간 이전이 본격화되는 세대가 에코세대인 것으로 볼 수 있다.

<표 2> 세대별 주택자금조달 방법(단위: \%)

\begin{tabular}{c|c|c|c|c}
\hline \multirow{2}{*}{ 전국 } & 본인마련 & 80.4 & 74.3 & 1960년대생 \\
\cline { 2 - 5 } & 금융기관대출 & 18.4 & 21.1 & 66.8 \\
\cline { 2 - 5 } & 부모지원 & 1.2 & 4.6 & 22.7 \\
\hline \multirow{3}{*}{ 서울 } & 본인마련 & 82.2 & 71.6 & 10.5 \\
\cline { 2 - 5 } & 금융기관대충숭 & 16.4 & 22.1 & 67.2 \\
\cline { 2 - 5 } & 부모지원 & 1.4 & 6.3 & 15.3 \\
\hline
\end{tabular}

\section{3. 에코세대 재무 특성 및 부동산투자 행태: 가계금융복지조사 분석}

에코세대의 부동산투자와 관련된 특성 및 결정요인을 살펴보기 위해서는 먼저 가구의 재무적 특징을 살펴볼 필요가 있다. 〈표 3〉에서는 세대별 가구의 재무적 특성에 대한 기초통계를 산출 하였다.

<표 3> 세대별 가구의 재무 특성 기초통계(단위: 만원)

\begin{tabular}{|c|c|c|r|r|r}
\hline & & mean & \multicolumn{1}{c}{ s.d. } & min & \multicolumn{1}{c}{$\max$} \\
\hline \multirow{4}{*}{39 세이하 } & 가구소득 & 5,340 & 3,601 & 0 & 45,568 \\
\cline { 2 - 6 } & 총자산 & 26,335 & 32,593 & 0 & 550,878 \\
\cline { 2 - 6 } & 총부채 & 6,659 & 12,293 & 0 & 256,449 \\
\cline { 2 - 6 } & 순자산 & 19,675 & 25,350 & $-20,618$ & 340,140 \\
\cline { 2 - 6 } & 소비지출 & 1,251 & 1,493 & 0 & 8,250 \\
\cline { 2 - 7 } & 비소비지출 & 954 & 1,304 & 0 & 42,242 \\
\hline
\end{tabular}




\begin{tabular}{|c|c|c|c|c|c|}
\hline & & mean & s.d. & $\min$ & $\max$ \\
\hline \multirow{6}{*}{ 40 49세 } & 가구소득 & 6,914 & 6,615 & 0 & 239,335 \\
\hline & 총자산 & 43,291 & 53,493 & 1 & 919,530 \\
\hline & 총부채 & 9,281 & 18,685 & 0 & 432,090 \\
\hline & 순자산 & 34,010 & 42,928 & $-19,190$ & 519,711 \\
\hline & 소비지출 & 1,644 & 2,130 & 0 & 16,313 \\
\hline & 비소비지출 & 1,410 & 2,492 & 0 & 87,000 \\
\hline \multirow{6}{*}{ 50 59세 } & 가구소득 & 7,178 & 6,966 & 13 & 112,190 \\
\hline & 총자산 & 47,584 & 75,335 & 1 & $1,345,750$ \\
\hline & 총부채 & 8,236 & 22,828 & 0 & 683,050 \\
\hline & 순자산 & 39,348 & 63,219 & $-122,423$ & $1,155,700$ \\
\hline & 소비지출 & 1,458 & 1,998 & 0 & 14,430 \\
\hline & 비소비지출 & 1,413 & 2,802 & 0 & 102,186 \\
\hline \multirow{6}{*}{ 60세이상 } & 가구소득 & 3,545 & 4,677 & 7 & 93,721 \\
\hline & 총자산 & 39,246 & 76,573 & 0 & $2,346,200$ \\
\hline & 총부채 & 4,795 & 19,402 & 0 & 750,000 \\
\hline & 순자산 & 34,451 & 65,621 & $-198,700$ & $1,746,200$ \\
\hline & 소비지출 & 805 & 1,233 & 0 & 20,030 \\
\hline & 비소비지출 & 535 & 1,501 & 0 & 47,858 \\
\hline \multirow{6}{*}{ 전체 } & 가구소득 & 5,364 & 5,819 & 0 & 239,335 \\
\hline & 총자산 & 40,053 & 67,180 & 0 & $2,346,200$ \\
\hline & 총부채 & 6,808 & 19,330 & 0 & 750,000 \\
\hline & 순자산 & 33,246 & 56,614 & $-198,700$ & $1,746,200$ \\
\hline & 소비지출 & 1,199 & 1,717 & 0 & 20,030 \\
\hline & 비소비지출 & 985 & 2,111 & 0 & 102,186 \\
\hline
\end{tabular}

먼저 전체 대상 기초통계를 살펴보면 다음과 같다. 분석 대상 전체의 가구소득 평균값은 약 5,364 만원 수준인 것으로 확인되고 있다. 총자산은 약 40,053만원 정도를 보유하고 있으며, 부채의 규모는 6,808만원 정도가 존재하고 있기 때문에 순자산은 약 33,246만원 수준인 것을 볼 수 있다. 연간 소비지출과 비소비지출 금액은 각각 1199 만원, 985 만원 정도로 평균치가 형 성되어 있다.

이를 세대별로 구분하여 살펴보면, 에코세대인 39세 이하의 가구소득은 5,340만원 수준으로 전체 평균보다 소폭 낮은 정도를 기록하고 있다. 연령이 높아지면서 40대의 가구소득은 약 6,914 만원, 50 대의 소득은 7,178 만원 정도를 기록하고 있기 때문에 연령이 높아질수록 소득 
수준이 급격히 높아지는 모습이 확인된다. 반면 60세 이상의 경우에는 경제활동인구에서 벗어 나 은퇴를 하는 시점이기 때문에 다른 연령대에 비하여 소득수준이 낮은 3,545만원 수준을 보 이고 있다. 한편 자산과 부채를 비교해보면, 에코세대에서의 자산 규모는 세대별로 소득을 비교 했을 때와 대비하여 상당히 낮은 수준을 보이고 있다. 에코세대의 총자산은 약 26,335만원 수 준을 기록면서 평균 대비 약 $65.7 \%$ 수준에 불과한 상황이다. 그러나 40 대의 총자산은 43,291 만원, 50대는 그보다 높은 47,584만원 정도로 형성되어 있다. 마찬가지로 60 대 이상의 총자산 은 39,246만원 수준으로 평균 정도의 자산이 형성되어 있는 것으로 나타난다. 부채규모도 세대 별 패턴은 그대로 적용되는데, 에코세대에서부터 50대까지는 자산 증가와 마찬가지로 부채도 증가하는 모습을 보인다. 그러나 60 대에서는 급격하게 하락하는 모습을 보여준다.

이상과 같은 현상을 통하여 미루어 짐작할 수 있는 부분은, 에코세대의 소득수준은 40 50대 의 소득보다 낮은 수준이지만 생애주기로 볼 때 더 높아질 가능성이 있기 때문에 기대소득 측면 에서 상승을 예상할 수 있다. 그러나 총자산규모는 에코세대에 비하여 40 50대의 자산규모가 큰 차이를 보이는 것이 확인된다. 따라서 향후 30 대 이하 세대들의 기대소득이 높아지면서 인 구동학적으로 주택 소유에 대한 주력 계층으로 높아질 가능성이 존재하는 것으로 생각된다. 앞 서 언급하였던 부의 세대간 이전 역시 가계금융복지조사의 기초통계를 통하여 확인할 수 있다. 60대 이상 세대에서는 총자산의 규모는 전체 평균수준이지만 평균 대비 낮은 모습을 보여주는 데, 이는 결국 60 대의 가처분소득 확보를 위하여 부동산 등의 자산을 처분할 가능성이 존재하 는 것으로 해석할 수 있다. 혹은 베이비부머 세대의 자산이 에코세대로 증여 등의 형태를 통하 여 이전될 가능성 역시 제기할 수 있는 것으로 볼 수 있다. 결국 에코세대는 아직 자산 형성이 진행되고 있는 과정에 위치한 세대이며, 40 50대와는 다르게 부모세대가 보유하고 있는 자산 의 세대간 이전까지 기대할 수 있다는 측면에서 주택시장의 주요 수요세대로 부상할 수 있는 가 능성이 존재하는 것으로 볼 수 있다.

다른 데이터베이스와는 다르게 가계금융복지조사에서는 부동산투자 의향에 대한 질문 문항 이 있기 때문에 부동산투자에 대한 결정요인에 대하여 분석할 수 있다. 이를 통하여 실거주 측 면에서의 수요보다는 자산수요로써의 부동산수요를 측정할 수 있다는 장점이 있다. 이를 살펴 보기 위하여 동 문항에 대한 기초통계를 산출한 결과는 〈표 4〉와 같다.

우선 여유자금 보유시 운용방식에 대한 선호도는 전체 가구를 대상으로 할 때 저축과 금융자 산 투자에 대한 비율이 가장 높은 $48.5 \%$ 가 응답한 것으로 확인되고 있다. 부동산 구입을 통한 자산 운용을 하겠다는 응답은 전체 가구 중 $24.6 \%$ 수준이며, 부채상환, 기타 순으로 높은 비율 을 차지하고 있다. 세대별로 구분하여 살펴보면 에코세대인 39세 이하 세대에서는 저축과 금융 
자산 투자에 대한 응답이 상대적으로 높은 반면 부동산구입은 40 50대 응답보다 소폭 낮은 것 이 확인된다. 이는 결국 아직까지 에코세대의 소득 및 축적된 금융자산 수준이 낮기 때문에 자 산 형성이 일정 수준까지 이루어진 후에 부동산을 투자하려고 하는 니즈가 있는 것으로 볼 수 있다. 한편 베이비부머 세대인 60대 이상은 부동산구입을 통한 자산운용을 하겠다는 응답 비중 이 다른 세대에 비하여 현저히 낮게 나타나고 있으며, 저축과 금융자산 투자에 대한 응답이 높 은 것으로 볼 때, 은퇴와 동시에 부동산자산을 추가로 확보하기보다는, 앞서 언급하였듯이 부의 세대간 이전을 통하여 자녀 세대로 이전되거나 혹은 현금 확보 후 유동성이 좀 더 높은 금융자 산으로의 전환을 꾀하고 있는 것으로 볼 수 있다. 부동산투자에 대한 결정만을 대상으로 질문해 보면 자금 운용방식과는 조금 다른 결과를 볼 수 있다. 에코세대의 부동산투자 의향이 다른 세 대에 비해서 가장 높은 것을 볼 수 있는데, 앞선 결과와 연결해보면 에코세대는 아직 자산축적 이 충분치 않기 때문에 우선적으로 자산 형성 이후 부동산투자를 하겠다는 의향을 가진 것으로 해석할 수 있다.

<표 4> 세대별 자금운용방식 조사결과

\begin{tabular}{c|c|c|c|c|c|c}
\hline \multirow{4}{*}{$\begin{array}{c}\text { 여유자금 } \\
\text { 운용방식 }\end{array}$} & $\begin{array}{c}\text { 저축과 } \\
\text { 금융자산 투자 }\end{array}$ & 40.4 & 34.7 & 40.4 & 63.3 & 48.5 \\
\cline { 2 - 7 } & 부동산구입 & 29.0 & 31.5 & 31.7 & 15.3 & 24.6 \\
\cline { 2 - 7 } & 부채상환 & 27.1 & 30.1 & 23.1 & 11.3 & 20.4 \\
\cline { 2 - 7 } & 내구재구입 & 2.8 & 2.3 & 2.1 & 1.9 & 2.2 \\
\cline { 2 - 7 } & 기타 & 0.6 & 1.3 & 2.7 & 8.3 & 4.4 \\
\hline \multirow{2}{*}{$\begin{array}{c}\text { 부동산투자결정 } \\
\text { 여부 }\end{array}$} & 부동산투자 하겠다 & 69.1 & 66.8 & 60.9 & 31.2 & 51.3 \\
\cline { 2 - 7 } & 투자하지 않겠다 & 30.9 & 33.2 & 39.1 & 68.8 & 48.7 \\
\hline
\end{tabular}

\section{IV. 실증분석 결과}

\section{1. 주택구입 결정요인 분석: 주거실태조사 활용}

앞선 장에서 언급하였듯이 에코세대의 주택매입에 대한 결정요인을 살펴보기 위해서 주거형 
태 및 부의 세대간 이전에 대한 중요성을 언급한 바 있다. 베이비부머 세대를 부모로 둔 에코세 대의 입장에서는 이와 같은 재원 조달이 중요한 역할을 할 수 있을 것으로 제시하였는데, 이를 증명하기 위하여 주거실태조사를 통한 내집마련 성공 결정요인을 살펴볼 수 있다. 아주 직관적 인 로짓모형 실증분석의 수식은 다음과 같다.

$$
H_{i}=\alpha+\beta X_{i}+\gamma C_{i}+\epsilon_{i}
$$

여기에서 $H_{i}$ 는 내집마련 성공여부를 의미하는 변수이고, $X_{i}$ 는 주택마련비용 중 부모의 기여 도를 나타낸다. 또한 $C_{i}$ 는 각 가구의 특성을 나타내는 통제변수의 집합으로 표현하였다. 결국 내집마련 성공 결정요인을 다른 변수들을 통제한 이후 부의 세대간 이전이 기여하는 부분이 통 계적으로 유의미한지 증명하였다. 한편 종속변수인 내집마련 성공여부는 성공했을 경우 1 , 아 직 마련하지 못했을 경우 0 의 값을 가지도록 정의하였고, 부모의 기여도는 주택마련을 위한 부 모의 지원금액을 의미한다.

한편 로짓분석은 세 가지의 시나리오로 진행되었는데, 먼저 내집마련 성공여부를 부모의 지 원금액만으로 설명하는 것을 model 1로 정의하였다. 단계적으로 변수를 추가하여 소득금액을 설명변수에 추가한 결과를 model 2로 제시하였으며, 가구특성변수를 추가로 도입한 모형을 model 3으로 하여 분석결과를 제시하도록 한다. 이 때 가구특성변수는 가구주연령, 가구주연 령제곱, 가구원수, 가구주 교육수준, 경제활동여부 등이 포함되었다.

분석 결과는 본 연구의 중점 대상인 에코세대와 그 이외의 세대로 나누어 분석을 진행하였고, 다음 〈표 5〉에서 결과를 제시하였다. 먼저 주된 설명변수인 부모의 지원금액 변수는 모든 세대 와 모형을 통틀어 $1 \%$ 의 유의수준에서 통계적으로 유의미한 결과를 보여주고 있다. 따라서 부모 의 지원금액은 내집마련에 있어서 중요한 결정요인인 것으로 볼 수 있다. 그런데 동 변수의 계 수값을 비교해보면, 모든 모형 결과에서 에코세대가 그 이외 세대보다 계수값이 높은 것을 볼 수 있다. 직접적인 비교는 어렵겠지만 간접적으로 볼 때 에코세대에서의 부모 지원이 다른 세대 보다 내집마련 결정에 더 중요한 요소인 것으로 해석할 수 있다.

한편 소득금액 역시 통계적 유의성이 높은 것을 볼 수 있다. 그런데 에코세대의 model 3에 서의 통계적 유의성이 낮은 것으로 나타나고 있는데, 이는 에코세대의 소득수준은 다른 세대에 비하여 내집마련 결정에 상대적으로 낮은 고려사항인 것으로 볼 수 있다. 연령 변수는 인구동학 적 관점에서 연령이 높을수록 내집마련에 성공했을 것이라는 가설을 설명하기에 충분한 수준으 로 나타나고 있다. 하지만 연령제곱이 음(-)의 값으로 추정되면서 연령이 증가할수록 내집마련 
에 성공하는 증가폭은 체감하는 것으로 확인된다. 세대별로 model 3의 결과만을 놓고 보면, 상 대적으로 에코세대에서는 부모의 지원이 다른 변수보다 중요한 결정요인으로 해석할 수 있다. 또한 연령제곱의 감소폭이 더 크게 나타나면서 부모지원의 중요성을 더욱 부각되는 것으로 이 해할 수 있다.

\section{<표 5> 세대별 내집마련 결정요인 분석 결과}

\begin{tabular}{|c|c|c|c|c|c|c|}
\hline & \multicolumn{3}{|c|}{ 에코세대 } & \multicolumn{3}{|c|}{ 40대 이상 } \\
\hline & Model 1 & Model 2 & Model 3 & Model 1 & Model 2 & Model 3 \\
\hline \multirow{2}{*}{ (로그)부모지원금액 } & $1.098 * * *$ & $0.707 * * *$ & $0.575 * * *$ & $0.394 * * *$ & $0.246 * * *$ & $0.268 * * *$ \\
\hline & $(0.0753)$ & $(0.0875)$ & $(0.102)$ & $(0.0477)$ & $(0.0518)$ & $(0.0563)$ \\
\hline \multirow{2}{*}{ (로그)소득금액 } & & $1.613 * * *$ & 0.348 & & $0.668 * * *$ & $0.729 * * *$ \\
\hline & & (0.198) & $(0.268)$ & & $(0.0822)$ & $(0.160)$ \\
\hline \multirow{2}{*}{ 연령 } & & & $1.071 * *$ & & & $0.342 * * *$ \\
\hline & & & $(0.418)$ & & & $(0.0510)$ \\
\hline \multirow{2}{*}{ 연령제곱 } & & & $-0.0144 * *$ & & & $-0.00206 * * *$ \\
\hline & & & $(0.00634)$ & & & $(0.000376)$ \\
\hline \multirow{2}{*}{ 가구원수 } & & & $0.634 * * *$ & & & $0.455 * * *$ \\
\hline & & & $(0.101)$ & & & (0.0909) \\
\hline \multirow{2}{*}{ 경제활동여부 } & & & 0.333 & & & $0.821 * * *$ \\
\hline & & & $(0.461)$ & & & $(0.216)$ \\
\hline \multirow{2}{*}{ 교육수준(고졸) } & & & -0.929 & & & $0.446 *$ \\
\hline & & & (2.126) & & & $(0.248)$ \\
\hline \multirow{2}{*}{ 교육수준(대졸이상) } & & & -1.025 & & & $0.539 *$ \\
\hline & & & $(2.121)$ & & & $(0.313)$ \\
\hline \multirow{2}{*}{ 상수항 } & $-9.980 * * *$ & $-15.69 * * *$ & $-27.74 * * *$ & $-1.631 * * *$ & $-3.829 * * *$ & $-18.93 * * *$ \\
\hline & $(0.650)$ & (1.124) & (7.102) & $(0.366)$ & $(0.471)$ & (1.931) \\
\hline 관측치 & 1,170 & 1,149 & 1,149 & 1,530 & 1,529 & 1,529 \\
\hline
\end{tabular}

주 : *은 $10 \%(p$-value〈0.1), **은 5\%(p-value〈0.05), ***은 $1 \%(p$-value〈0.01)의 유의수준에서 유의함을 의미하며, 괄호는 표준오차를 의미함 


\section{2. 부동산투자 결정요인 분석: 가계금융복지조사 활용}

지금까지 분석된 내집마련 결정요인에 대한 분석결과는 주거실태조사를 통하여 진행된 것인 데, 이는 실거주 수요측면에서의 주택수요인 것으로 볼 수 있다. 따라서 추가적으로 부동산 취 득으로써의 자산수요를 살펴볼 필요가 있다. 이를 분석하기 위하여 가계금융복지조사 데이터베 이스를 활용한 분석을 진행하였다. 분석모형은 다음과 같다.

$$
I_{i}=\alpha+\beta_{1} \operatorname{sex}_{i}+\beta_{2} \text { age }_{i}+\beta_{3} \text { marriage }_{i}+\beta_{4} H H_{i}+\epsilon_{i}
$$

여기에서 $I_{i}$ 는 부동산투자 결정여부에 대한 변수로써 부동산투자 용의가 있으면 1 , 그렇지 않 으면 0 으로 정의되었다. $\operatorname{sex}$ 는 가구주 성별을 의미하고, $a g e_{i}$ 는 가구주연령 변수로 정의되며, marriage $_{i}$ 는 가구주의 혼인여부를 의미하는 변수이다. $H H_{i}$ 는 가구의 특성을 의미하는 변수로 서, 여기에 포함되는 변수는 가구소득, 가구자산, 가구부채, 자가여부, 가구원당 주택면적을 포 함하는 변수로 정의할 수 있다.

〈표 6〉에서는 세대별 부동산투자 결정요인에 대한 실증분석 결과를 제시하였다. 먼저 성별은 모든 세대의 분석결과에서 부동산투자 결정에 영향을 미치지 않는 것으로 나타났다. 반면 연령 변수는 60대를 제외한 나머지 세대에서는 연령이 증가할수록 부동산에 대한 투자 결정이 이루 어지는 것으로 나타났다. 60 대 이상 고령층에서는 연령이 부동산투자와 상관이 없는 것으로 나 타나고 있는데, 이는 부동산투자에 대한 니즈가 내집마련에서 증여 등으로 목적이 바뀌는 것에 기인하는 것으로 생각할 수 있다. 또한 자가에 거주하는 사람보다 임차 거주가구의 부동산투자 의향이 더 높은 것도 내집마련에 대한 수요가 존재하는 것으로 해석된다.

한편 가구의 소득, 자산, 부채와 관련해서는 일반적으로 인식되고 있듯이, 소득이 높을수록, 자산이 많을수록, 부채가 적을수록 부동산투자에 대한 의지가 존재하는 것으로 분석되었다. 그 런데 세대별 구분을 해보면, 에코세대의 경우 소득과 부채변수는 부동산투자 결정에 대한 통계 적 유의성이 없는 것으로 나타나고 있다. 이는 에코세대의 주택자산에의 투자에 있어서 소득과 부채가 중요한 고려사항이 아니라는 것으로 해석할 수 있다. 따라서 다른 세대에 비하여 에코세 대는 앞선 내집마련 결정요인에서 볼 수 있듯이 부모의 지원을 일정 수준 받은 이후 본인의 소 득 및 부채와 관련없이 주택을 구매하는 패턴을 보이는 것으로 해석할 수 있다.

반면 고령층에서는 현재 자산과 투자결정에 대한 관련성이 낮게 나타난다. 이와 같은 현상을 종합해보면 부동산투자에 대한 결정은 연령대별로 상이한 요인에 의하여 결정되는데, 젊은 세 
대는 내집마련을 위해 부채나 소득수준과 관계없이 투자에 대한 결정을 하는 것으로 나타나는 반면 실수요에 따른 면적은 크게 고려하지 않는 것으로 볼 수 있다. 반면 고령층은 부채관리 등 을 중시하는 경향을 보이기 때문에 부채가 증가하면 상환에 대한 부담 등으로 인하여 부동산투 자를 꺼려하는 것으로 해석할 수 있다. 다만 자녀 상속에의 의지 등에 대한 요구는 가계금융복 지조사를 활용한 분석 결과에는 나타나지 않고 있으나 앞선 주거실태조사를 통한 부모지원과 내집마련의 관계를 분석한 결과에서 짐작할 수 있을 것으로 생각된다.

<표 6> 세대별 부동산투자 결정요인 분석결과

\begin{tabular}{|c|c|c|c|c|}
\hline & 전체 대상 & 에코세대 & 40 50대 & 60 대 이상 \\
\hline \multirow{2}{*}{ 성별 } & 0.00958 & 0.0685 & 0.0229 & -0.0842 \\
\hline & $(0.0768)$ & (0.184) & (0.108) & $(0.143)$ \\
\hline \multirow{2}{*}{ 연령 } & $0.135 * * *$ & $0.727 * * *$ & $0.255 * *$ & -0.118 \\
\hline & $(0.0140)$ & $(0.237)$ & (0.118) & (0.118) \\
\hline \multirow{2}{*}{ 연령제곱 } & $-0.001 * * *$ & $-0.011 * * *$ & $-0.003 * *$ & 0.000 \\
\hline & $(0.000)$ & $(0.004)$ & $(0.001)$ & $(0.001)$ \\
\hline \multirow{2}{*}{ 혼인여부 } & $0.348 * * *$ & 0.248 & $0.332 * * *$ & $0.562 * * *$ \\
\hline & $(0.074)$ & $(0.172)$ & (0.103) & $(0.148)$ \\
\hline \multirow{2}{*}{ 가구소득 } & $0.002 * * *$ & -0.001 & 0.001 & $0.002 * *$ \\
\hline & $(0.001)$ & $(0.002)$ & $(0.001)$ & $(0.001)$ \\
\hline \multirow{2}{*}{ 가구자산 } & $0.000 * * *$ & $0.001 * *$ & $0.000 * * *$ & 0.000 \\
\hline & $(0.000)$ & $(0.000)$ & $(0.000)$ & $(0.000)$ \\
\hline \multirow{2}{*}{ 가구부채 } & $-0.001 * * *$ & -0.001 & $-0.001 * * *$ & $-0.001 * *$ \\
\hline & $(0.000)$ & $(0.001)$ & $(0.000)$ & $(0.000)$ \\
\hline \multirow{2}{*}{ 자가여부 } & $-0.648 * * *$ & $-0.652 * * *$ & $-0.531 * * *$ & $-0.945 * * *$ \\
\hline & $(0.056)$ & $(0.136)$ & $(0.075)$ & $(0.109)$ \\
\hline \multirow{2}{*}{ 가구원당 주택면적 } & $-0.002 *$ & -0.007 & 0.001 & $-0.003 *$ \\
\hline & $(0.001)$ & (0.005) & $(0.002)$ & $(0.002)$ \\
\hline \multirow{2}{*}{ Constant } & $-3.823 * * *$ & $-12.99 * * *$ & $-7.219 * *$ & 5.040 \\
\hline & $(0.367)$ & (3.838) & (2.929) & $(4.192)$ \\
\hline 관측치 & 9,379 & 1,422 & 4,170 & 3,787 \\
\hline
\end{tabular}

주 : *은 10\%(p-value〈0.1),**은 5\%(p-value〈0.05),***은 1\%(p-value〈0.01)의 유의수준에서 유의함을 의미하며, 괄호는 표준오차를 의미함 
추가적으로 40 50대의 경우 에코세대에 반해 혼인과 부채가 통계적으로 의미 있는 요인으 로 부각되고 있다. 하지만 40 50대가 주택을 구매할 때 자가소유의 여부는 다른 두 세대보다 낮은 영향력을 보인다. 이는 40 50대가 결혼 후 가족이 늘어나고 자식들이 성장하면서 기존의 주택보다 확장 또는 개선된 주택을 선택해야하는 시기와 맞물려 나타나는 현상으로 풀이될 수 있다. 또한 부채에 대한 걱정이 60대 이상의 수준으로 나타나면서 추가적인 부모의 지원이 에 코세대만큼 용이하지 않음을 유추할 수 있다.

\section{V. 결론 및 정책적 시사점}

본 연구에서는 베이비부머 세대의 자녀세대로 통칭되는 에코세대의 주택 수요와 관련된 결정 요인을 살펴보았다. 여러 기존연구에서 확인되고 있듯이 기존 세대와 에코세대의 주택 수요 패 턴은 사뭇 다른 모습을 보이는 것으로 볼 수 있다. 특히 경제발전 단계에서의 시간의 흐름에 따 른 국가 전체의 부와 자산 측면으로 보면, 베이비부머 세대는 그들의 부모세대에게서 부를 이전 받을 것이 크지 않았다면, 현재의 에코세대는 부의 세대간 이전이 가능한 상황에 위치하고 있기 때문에 주택 구입 등의 형태에 있어서도 이전 세대와는 다른 패턴이 발생하는 것으로 보인다.

본 연구에서 찾을 수 있는 함의로써, 이현정(2013)에서 언급되었듯이 에코세대는 부동산에 대해 궁극적으로 내집마련에 대한 가치관은 기성세대와 동일하나, 자신들의 소득수준보다는 라 이프스타일과 더불어 투자의 방법으로 활용하고 자산을 형성하고자 하는 것이 특징이라 할 수 있다. 물론 제도적 요인에 의해 금융대출이 제약되어 있지만 세대간 이전 또는 기성세대들이 기 존의 주택을 마련하는 방법과는 다르게 부동산에 투자하고 있다.

또한 김태경(2009)에서 제시한 결과를 좀 더 실증적으로 분석한 결과, 현재 에코세대의 노동 시장에서 좋지 못한 상황과 그들의 부채, 높은 실업에 따른 낮은 자산 형성에도 불구하고, 높은 주거비에도 에코세대만의 라이프스타일을 추구하고 내집마련이라는 가치관을 실현하기 위해 기존의 통념 보다는 적극적인 모습이 일부 확인되는 것이 본 연구에서 주요한 점이다.

주거실태조사를 활용한 내집마련 결정요인 분석결과 모든 세대에서 부모의 지원금액이 내집 마련 결정에 중요한 영향을 주는 것으로 나타나고 있으나 추정계수의 크기를 비교해보면 에코 세대가 좀 더 많은 영향을 받는 것으로 볼 수 있다. 또한 소득수준이 상대적으로 영향을 적게 주 는 변수인 만큼 부의 세대간 이전이 중요하게 작용한다고 볼 수 있다. 한편 부동산투자 결정요 
인에서 볼 수 있듯이 에코세대의 부동산투자는 그들의 소득 및 부채 등의 변수와는 무관하게 결정 되는 것으로 볼 때 기존 주택수요 분석과는 다른 방식으로의 접근이 필요한 것으로 볼 수 있다.

따라서 향후 주택수요 및 주거형태에 대한 분석을 진행함에 있어서 세대별로 다른 패턴이 발 생하는 동시에 새로운 요소인 부의 세대간 이전이라는 항목이 추가로 고려되어야 할 것이다. 최 근 발생하고 있는 출산율 감소와 1 인가구화, 그리고 고령화 등을 반영하여 분석이 진행되어야 하지만 사실 자산의 이전이라는 측면에서 접근한다면 세대를 구분하여 주택의 실거주 및 자산 으로써의 수요를 파악하는 것이 중요한 것으로 생각된다.

\section{참교문헌}

강민규·최막중 - 김준형, “주택의 자산효과에 의한 가계소비 변화: 자가가구 미시자료를 이용한 실증분석”, 『국토계획』, 제44권 제5호, 대한국토·도시계획학회, 2009, pp. 163-173.

김경환, “부동산가격과 거시경제간의 상호관계”, 『자산가격 변동에 대응한 통화정책방향』, 한국은행 조사 국, 2003.

김준형·최막중, “주택가격이 기혼여성의 노동활동에 미치는 영향”, 『국토계획』, 제42권 제3호, 대한국토 · 도시계획학회, 2007, pp.203-214.

김태경, “주택의 소유유형에 따른 소유회전율 결정요인에 관한 연구”, 국토계획 : 대한국토도시계획회지, 제44권 제3호, 대한국토·도시계획학회, 2009, pp.125-135.

박천규·이수욱·손경환, “가구생애주기를 감안한 주택수요특성 분석 연구," 국토연구, 60권, 국토연구원, 2009, pp.171-187.

여윤경, “한국 중산층 가계의 노후자금 적정성”, 한국노년학 25권 1호, 한국노년학회, 2005, pp.21-36. 여윤경 · 주소현. "가계의 순자산과 자산 배분에 관한 연구. 산업경제연구”, 22권 5호, 2009, pp.2109-2129. 우윤석 · 이은정, "언론보도와 시계열 주택가격 간의 관계에 관한 연구", 주택연구, 19권 제4호, 한국주택학회, 2011, pp.111-134.

이소영·정의철, “패널자료를 이용한 청년층 임차가구의 자가 전환 결정요인 분석”, 주택연구, 25권 1호, 한국주택학회, (2017), pp.63-89.

이수욱 · 김태환 · 황관석·변세일 · 이형찬, “저성장시대 청년층 주거안정을 위한 정책방안 연구”, 국토연 구원, 2015.

이용만, “구조적 변화인가 가격상승의 징조인가?”, 부동산학연구, 6권 1호, 한국부동산분석학회, 2000, pp.9-22.

이현정, “예비 사회진출자의 졸업 후 주거에 대한 기대 및 주거비 부담에 대한 인식”, 한국주거학회논문집 24권 제4호, 2013, pp.29-37

이현정 · 김영주. “주택점유형태에 따른 청년층 가구의 사회경제적 차이 및 주택자산효과 분석”. 도시행정 
학보, 31권 2호, 2018, pp.73-95.

정의철, “주택점유형태의 동태적 결정요인에 관한 연구”, 주택연구, 25권 4호, 한국주택학회, 2017, pp.181-209.

최막중 - 강민욱, “주택 소유와 거주의 불일치 원인에 관한 실증분석”, 주택연구, 제20권 제2호, 한국주택 학회, 2012, pp.33-48.

최막중 · 고진수, "주택유형간 유동성 차이에 관한 연구, 국토계획: 대한국토도시계획회지, 제41권 제3호, 대한국토·도시계획학회, 2006, pp.83-93.

홍현옥 · 박령선, “가계의 주거소유효과 평가를 위한 분석모형 탐색” 주택연구, 제6권 제1호, 한국주택학 회, 1998. pp.33-52.

Andrew, Mark, Donald Haurin and Abdul Munasib, "Explaining the Route to Owneroccupation: A Transatlantic Comparison,” Journal of Housing Economics, Vol.15, Issue3, 2006, pp.189-216.

Artle, R., and P. Varaiya, "Lifecycle Consumption and Homeownership," Journal of Economic Theory, Vol.18, 1978, pp.38-58.

Brueckner, J., "The downpayment constraint and housing tenure choice," Regional Science and Urban Economics, Vol.16, 1986, pp.519-525.

Dietz, Robert and D. Haurin, "The social and private micro-level consequences of homeownership,", Journal of Urban Economics, Vol.54, 2003, pp.401-450.

Goodman, Allen, "An Econometric Model of Housing Price, Permanent Income, Tenure Choice, and Housing Demand," Journal of Urban Economics, Vol.23, 1988, pp.327-353.

Guiso, Luigi, Michael Haliassos, and Tullio Jappelli, eds. Household portfolios. MIT press, 2002.

Haurin, D.R., P.H. Hendershott and S.M. Wachter, "Borrowing Constraints and the Tenure Choice of Young Households," Journal of Housing Research. Vol.8, Issue2, 1997, pp.137-154.

loannides, Y. M., and Rosenthal, S. S. Estimating the consumption and investment demands for housing and their effect on housing tenure status. 1994

Tversky, A., and Kahneman, D. "Loss aversion in riskless choice: A reference-dependent model. The quarterly journal of economics, Vol.106, Issue4, 1991 pp.1039-1061.

Jones, L.D., "Current Wealth constraints on the housing demand of young owners," The Review of Economics and Statistics, Vol.72, 1990, pp.424-432.

Painter, G. and K. Lee, "Housing Tenure Transitions of Older Households: Life Cycle, Demographic, and Family Factors," Regional Science and Urban Economics, Vol.39, 2009, pp.749-760.

Plaut, S.E., "The timing of housing tenure transition," Journal of Urban Economics, Vol.21, 1987, pp.312-322. 